\title{
RNA-seq based gene expression analysis of ovarian granulosa cells exposed to zearalenone in vitro: significance to steroidogenesis
}

\author{
Guo-Liang Zhang ${ }^{1,2,3}$, Rui-Qian Zhang ${ }^{1}$, Xiao-Feng Sun ${ }^{1}$, Shun-Feng Cheng ${ }^{1}$, Yu-Feng \\ Wang $^{1}$, Chuan-Liang $\mathrm{Ji}^{2}$, Yan-Zhong Feng ${ }^{4}$, Jie $\mathrm{Yu}^{2}$, Wei $\mathrm{Ge}^{1}$, Yong Zhao ${ }^{1}$, Shi-Duo \\ Sun ${ }^{3}$, Wei Shen ${ }^{1}$ and Lan $\mathbf{L i}^{1}$ \\ ${ }^{1}$ College of Animal Science and Technology, Qingdao Agricultural University, Qingdao, Shandong 266109, China \\ ${ }^{2}$ National Engineering Research Center for Gelatin-Based Traditional Chinese Medicine, Dong-E-E-Jiao Co., Ltd, Liaocheng, \\ Shandong 252000, China \\ ${ }^{3}$ College of Animal Science and Technology, Northwest A\&F University, Yangling, Shaanxi 712100, China \\ ${ }^{4}$ Institute of Animal Sciences, Heilongjiang Academy of Agricultural Sciences, Harbin, Heilongjiang 150086, China \\ Correspondence to: Lan Li, email: lilan9600@126.com \\ Keywords: porcine, granulosa cells, steroidogenesis, gene expression, RNA-seq \\ Received: April 16, $2017 \quad$ Accepted: June 20,2017 Published: July 31, 2017 \\ Copyright: Zhang et al. This is an open-access article distributed under the terms of the Creative Commons Attribution License 3.0 \\ (CC BY 3.0), which permits unrestricted use, distribution, and reproduction in any medium, provided the original author and source \\ are credited.
}

\section{ABSTRACT}

Zearalenone (ZEA) is a natural contaminant of various food and feed products representing a significant problem worldwide. Since the occurrence of ZEA in grains and feeds is frequent, the present study was carried out to evaluate the possible effects of ZEA on steroid production and gene expression of porcine granulosa cells, using RNA-seq analysis. Porcine granulosa cells were administered $10 \mu \mathrm{M}$ and 30 $\mu M$ ZEA during $72 \mathrm{~h}$ of culture in vitro. Following ZEA treatment the gene expression profile of control and exposed granulosa cells was compared using RNA-seq analysis. The results showed that in the exposed granulosa cells ZEA significantly altered the transcript levels, particularly steroidogenesis associated genes. Compared with the control group, $10 \mu \mathrm{M}$ and $30 \mu \mathrm{M}$ ZEA treatment significantly increased the mRNA expression of EDN1, IER3, TGF $\beta$ and $B D N F$ genes and significantly reduced the MRNA expression of IGF-1 and SFRP2 genes. In particular, ZEA significantly decreased the expression of genes essential for estrogen synthesis including FSHR, CYP19A1 and HSD17 $\beta$ in granulosa cells. Furthermore, Q-PCR and Western-blot analysis also confirmed reduced expression of these genes in ZEA exposed granulosa cells. These effects were associated with a significant reduction of $17 \beta$-estradiol concentrations in the culture medium of granulosa cells. Collectively, these results demonstrated a concretely deleterious effect of ZEA exposure on the mRNA expression of steroidogenesis related genes and the production of steroid hormones in porcine ovarian granulosa cells in vitro.

\section{INTRODUCTION}

Zearalenone (ZEA) is a toxic compound produced by several species of Fusarium and causing mycotoxicosis in animals [1]. In the past few years, reports on the metabolism of ZEA in mammals were published. Because of its estrogenic activity, ZEA could cause reproductive disorders in domestic animals and estrogenic syndromes in humans [2].
Pigs appear to be more sensitive to the exposure of dietary ZEA than other animals [1]. In young swine, after a single oral administration, ZEA is rapidly absorbed and metabolized in vivo. The absorption of ZEA in swine was estimated to be $80-85 \%$ following administration of an oral dose of $10 \mathrm{mg} / \mathrm{kg}$ bodyweight [3]. ZEA has been detected in the follicular fluid of porcine antral follicles using liquid chromatography tandem mass spectrometry, and the concentrations of $\alpha$-ZEA and ZEA 
in porcine follicular fluid were $17.6 \mathrm{pg} / \mathrm{ml}$ and $38.9 \mathrm{pg} /$ $\mathrm{ml}$ respectively [4]. The effects of ZEA on weaned and prepubertal gilts have been described as vulvar and uterine hypertrophy, ovarian atrophy and mammary enlargement [5]. ZEA causes sterility in sows through inciting disorders of the ovary [6]. The oocytes die in primordial follicles, and despite having signs of estrus there is no ovulation [7]. Moreover, ZEA and its derivatives act similarly to $17 \beta$-estradiol $\left(\mathrm{E}_{2}\right)$ in inhibiting the secretion and release of steroid hormones, thus disrupting endogenous estrogenic response during the preovulatory stage and depressing the maturation of ovarian follicles [8]. Changes in the estrous cycle, induced by ZEA, depend on the dose and time of administration [8].

The mammalian ovaries are female reproductive organs consisting of oocytes, granulosa and theca cells. Follicle growth is based on the growth of granulosa cells and oocytes in the early stages, and steroidogenesis is also accelerated by follicle development [9, 10]. Granulosa cells surround oocytes and produce ovarian steroid hormones, including estrogen and progesterone [11]. Ovarian steroids are essential for the function and normal development of several organs, including the uterus, mammary glands and the brain. In addition, ovarian steroids have local effects that are critical for maintaining normal ovarian physiology. Steroidogenesis, the pathway of steroid hormone biosynthesis, begins with cholesterol as the initial substrate. In the majority of mammals, steroidogenesis appears to occur via the two cell/two gonadotropin model in which androgens are synthesized from cholesterol by luteinizing hormone $(L H)$ responsive theca cells, followed by conversion to estrogens in follicle stimulating hormone (FSH) exposed granulosa cells [12]. The $F S H$ receptor $(F S H R)$ is widely known as a representative biomarker during the folliculogenesis [13, 14]. The first stage of steroidogenesis is steroidogenic acute regulatory protein $(S T A R)$-mediated transportation of cholesterol into the mitochondria. $L H$ receptor $(L H R)$ and the enzyme $17 \alpha$-hydroxylase (CYP17A1), which converts pregnenolone by $3 \beta$-hydroxysteroid dehydrogenase $(H S D 3 \beta)$ and progesterone to dehydroepiandrosterone and androstenedione, respectively, are expressed primarily in theca cells, while FSHR and 19 $\alpha$-hydroxylase (CYP19A1), which convert androgens to estrogens, are expressed mainly in granulosa cells [15].

Porcine follicular atresia caused by granulosa cell apoptosis may be one of the most dominant factors affecting prepubertal porcine reproduction. Previous studies indicated that a high concentration $(\geq 60 \mu \mathrm{M})$ of ZEA could induce apoptosis in porcine granulosa cells as a result of disrupting porcine ovarian steroidogenesis [16]. Interestingly, our previous results demonstrated that low concentration $(10 \mu \mathrm{M})$ ZEA exposure may affect the functions of the ovary, such as female germ cell cyst breakdown, and primordial follicle formation and development [17]. The present study utilized RNA-seq analysis to verify whether ZEA exposure can affect the
mRNA expression and steroidogenesis of granulosa cells in vitro.

\section{RESULTS}

\section{ZEA exposure affects granulosa cell development and gene expression}

Porcine granulosa cells were cultured in vitro and exposed to $10 \mu \mathrm{M}$ or $30 \mu \mathrm{M}$ ZEA for $72 \mathrm{~h}$ (Figure $1 \mathrm{~A}$ ). The percentages of TUNEL positive granulosa cells significantly increased following ZEA exposure $(10 \mu \mathrm{M}$ : $29.07 \pm 0.78 \% ; 30 \mu \mathrm{M}: 57.47 \pm 0.93 \%)$ compared with that of the control group $(0 \mu \mathrm{M}: 8.81 \pm 0.57 \% ; P<0.01$; Figure 1B-1C). As shown in Figure 1D, the ratios of Bax/ $B c l-2$ mRNA expression significantly increased in $10 \mu \mathrm{M}$ $(1.49 \pm 0.19$ fold $)$ and $30 \mu \mathrm{M}(2.94 \pm 0.41$ fold $) \mathrm{ZEA}-$ exposed granulosa cells compared with that of the control group $(P<0.01)$.

To analyze the effects of ZEA exposure on porcine granulosa cells, RNA-seq of granulosa cells was performed. According to the research criterion FDR (False Discovery Rate) $<0.1$, a total of 25324 genes were screened, including 6374 differentially expressed genes (DEGs) between control and ZEA treatment groups, 2 926 DEGs between $10 \mu \mathrm{M}$ and $30 \mu \mathrm{M}$ ZEA treatment groups (Figure 2A). The number of DEGs caused by 10 $\mu \mathrm{M}$ and $30 \mu \mathrm{M}$ ZEA were 381 and 1979 respectively. We obtained three repeats of expressed genes from $0 \mu \mathrm{M}, 10$ $\mu \mathrm{M}$ and $30 \mu \mathrm{M}$ ZEA-treated granulosa cells RNA-seq data. One repeat of control groups was abandoned with a wide variation (Figure 2C-2D). Then the heat map was produced from the results of DEGs (Figure 2B). In this study, we chose the DEGs whose degree were greater than 20 from $0 \mu \mathrm{M}$ group $v s 10 \mu \mathrm{M}$ group, and $0 \mu \mathrm{M}$ group $v s$ $30 \mu \mathrm{M}$ group, respectively.

There were 6 genes selected from the DEGs between control and ZEA-treated groups to verify the RNA-seq analysis data. As shown in Figure 3, ZEA exposure significantly down-regulated the mRNA abundance of Insulin Like Growth Factors 1 (IGF1) and Secreted Frizzled Related Protein 2 (SFRP-2) genes, and significantly up-regulated the mRNA levels of Transforming Growth Factor Beta Receptor $(T G F-\beta)$, Brain Derived Neurotrophic Factor $(B D N F)$, Immediate Early Response 3 (IER-3), and Endothelin 1 (EDN-1) genes compared to that of the control groups ( $p$-value $<$ $0.05, q$-value $<0.1$ ), and the results of the Q-PCR were similar to those of the RNA-seq data analysis.

To explore the possible mechanism of ZEA exposure on porcine granulosa cells, we used the Search Tool for the Retrieval of Interacting Genes (STRING) database to annotate functional interactions between DEGs of the control and ZEA-treated groups. Based on this information, a protein-protein interaction (PPI) network was visualized by Cytoscape (Supplementary Figure 2). 
Due to the complex and large number of the protein interactions, the DEGs with greater than 20 degree were selected between the control and ZEA-treated groups to visualize the sub-network of the PPI network (Supplementary Figure 2). Analyzing the center nodes of the networks we observed that in the $0 \mu \mathrm{M}$ and 10 $\mu \mathrm{M}$ ZEA-treated groups, the Cyclin B $(C C N B)$ encoded protein interacted with most of the DEG encoded proteins predicting strong interaction with 87 of these proteins. The remaining key nodes of the network were the Polo like Kinase-1 (PLK-1), EDN-1, IGF-1, SMAD Family Member (SMAD-6) and FSHR (Supplementary Figure 2A). The number of interactions (degree) were 70, 52, 41, 50 and 48 , respectively. In the network of $0 \mu \mathrm{M}$ and 10 $\mu \mathrm{M}$ ZEA-treated groups, $T G F-\beta$ was the protein with the highest interactions, showing strong interactions with 102 DEG encoded proteins. The remaining key nodes were $B c l-2$ Associated X Protein $(B A X), E D N-1, I G F-1$, and the degree were 63, 87 and 95, respectively (Supplementary Figure 2B).

\section{DEGs involved in gene ontology (GO) classification and kyoto encyclopedia of genes and genomes (KEGG) pathways}

We obtained three groups of DEGs by comparing each group from the $0 \mu \mathrm{M}, 10 \mu \mathrm{M}$ and $30 \mu \mathrm{M}$ ZEA-treated granulosa cells. Then Venn diagrams were constructed by the results. The number of shared DEGs caused by $10 \mu \mathrm{M}$ and $30 \mu \mathrm{M}$ ZEA treatment was 164 (Figure 4A). We used DAVID to identify GO-enriched functions for the 164 DEGs (Figure 4B). The DEGs from the granulosa cells treated with ZEA were significantly enriched in cell cycle, cell cycle process, regulation of cell cycle, mitotic cell cycle, cell growth and mitotic cell cycle process (Figure 4C). These functions were significantly associated with cell cycle and metabolic regulation of granulosa cells. In addition, the downregulation of DEGs from the granulosa cells treated with ZEA were significantly enriched in cell cycle $(\mathrm{p}<1.66 \mathrm{E}-5)$, mitosis $(\mathrm{p}<7.97 \mathrm{E}-5)$, and metabolic process $(\mathrm{p}<0.000182)$ (Table 1$)$.

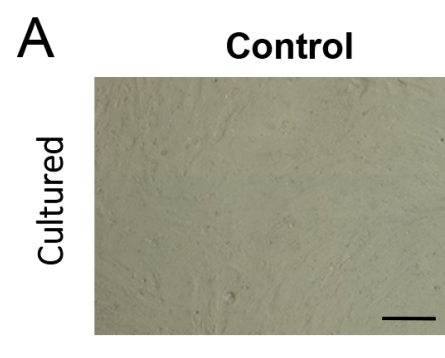

B

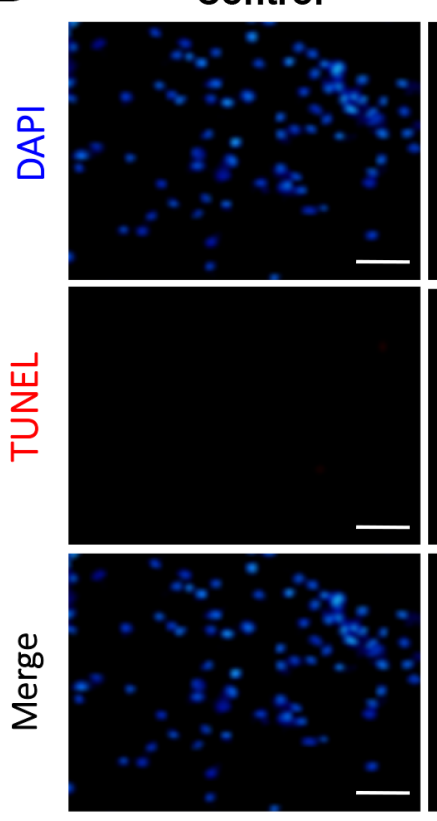

$10 \mu \mathrm{M}$

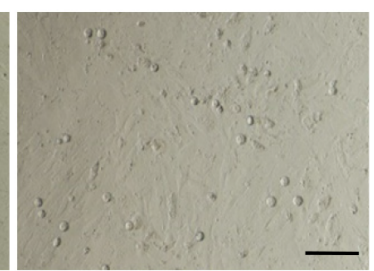

$10 \mu \mathrm{M}$
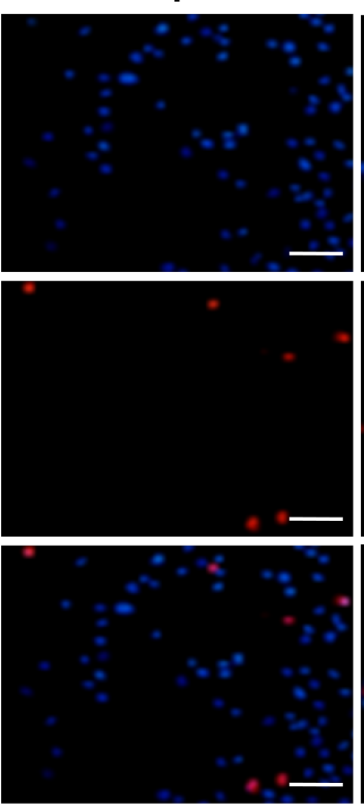

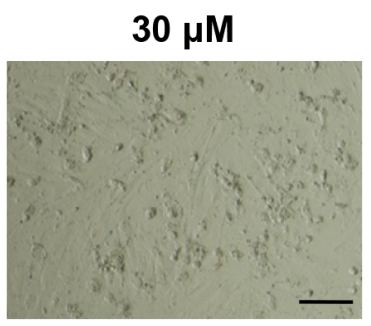

$30 \mu \mathrm{M}$
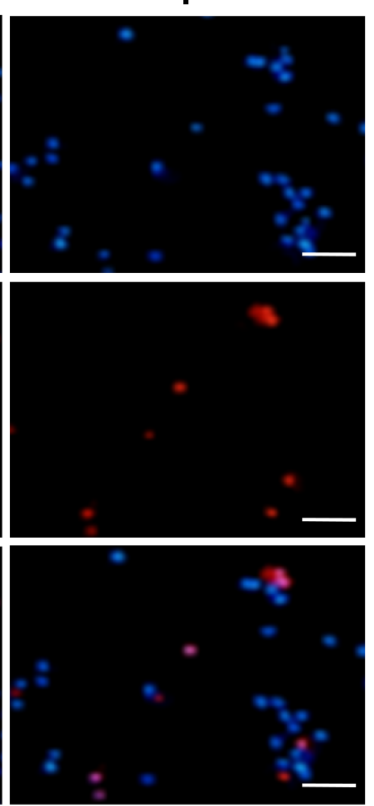

C

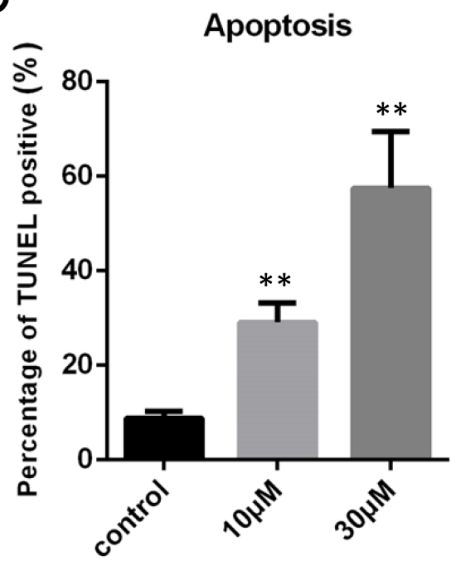

$\mathrm{Bax} / \mathrm{Bcl}-2$

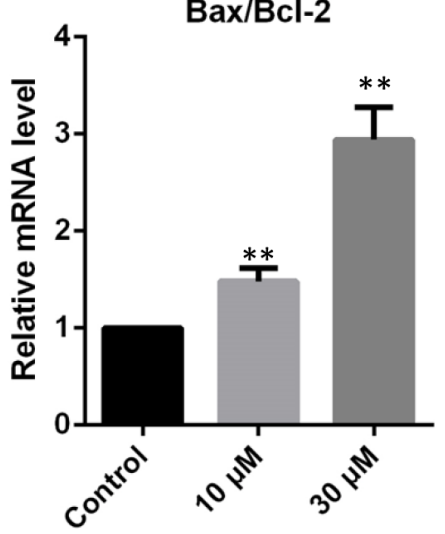

Figure 1: ZEA exposure increased cell apoptosis and induced the apoptosis-related gene mRNA abundance in cultured granulosa cells. (A) Cultured granulosa cells in vitro. (B) Immunofluorescent staining of TUNEL and DAPI. Bars indicate $50 \mu \mathrm{m}$. (C) Graph indicating the percentages of TUNEL positive granulosa cells. (D) The mRNA levels of Bax/Bcl-2 in cultured granulosa cells exposed to ZEA and control groups as determined by Q-PCR. The results are presented as mean $\pm \mathrm{SD}$. All experiments were repeated at least three times. ${ }^{*} P<0.05$; $* * P<0.01$. 
The $\mathrm{R}$ package of clusterProfiler was used to determine profoundly affected KEGG pathways in order to obtain further insights into the function of the DEGs. A total of the control and ZEA treatment group DEGs, containing 114 genes down-regulated and 50 genes upregulated in the ZEA exposure granulosa cells, were selected. On the basis of the results, the downregulated
DEGs were significantly enriched in the $T G F-\beta$ signaling pathway $(\mathrm{p}=0.000737$, $\mathrm{q}$-value $=0.030)$, Gap junction $(\mathrm{p}=0.001254$, q-value $=0.030)$, and $G n R H$ signaling pathway ( $p$-value $=0.001306, q$-value $=0.030)($ Table 2$)$. In addition, we obtained 20 core DEGs from the enriched pathway (Supplementary Figure 3, Table 3). Finally, by performing the KEGG pathway analysis of DEGs we
A

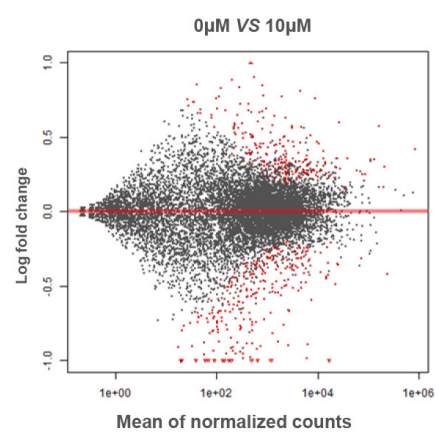

B

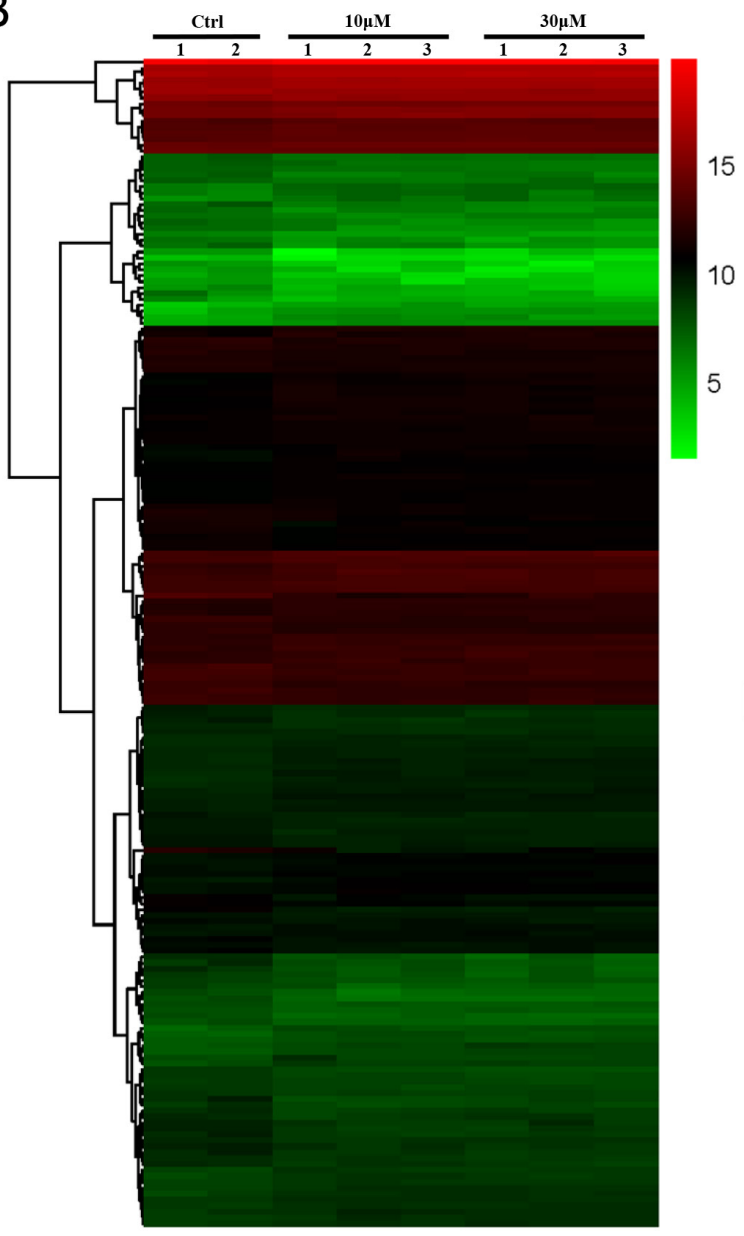

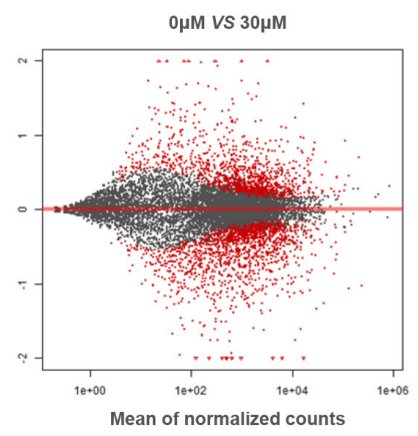

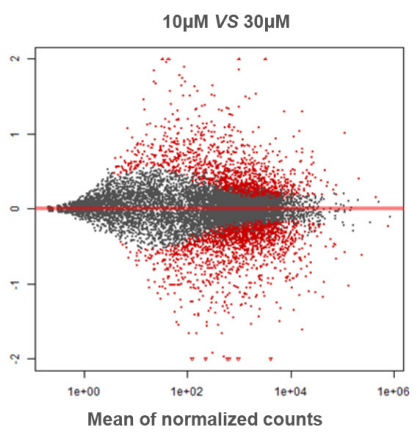

C

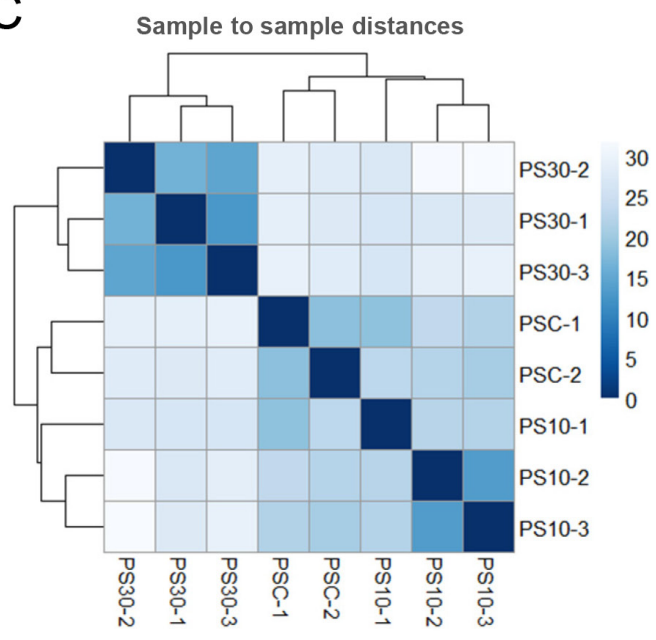

D

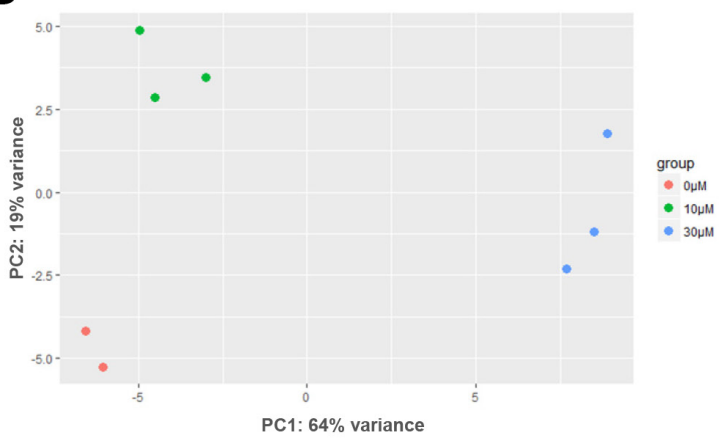

Figure 2: Granulosa cell gene expression profiling after ZEA treatment. (A) Scatterplot of gene expression after ZEA treatment. Control group vs. $10 \mu \mathrm{M}$ ZEA-treatment group, Control group vs. $30 \mu \mathrm{M}$ ZEA-treatment group, $10 \mu \mathrm{M}$ ZEA-treatment group vs. $30 \mu \mathrm{M}$ ZEA-treatment group. Red points represent genes expressed significantly different. (B) Heatmap indicating the group differences of DEGs in the $10 \mu \mathrm{M}$ and $30 \mu \mathrm{M}$ ZEA-treated groups compared with the control group, and the repeatability within each group. (C) Sample-tosample distances. Heatmap showing the Euclidean distances between the samples as calculated from the normalized log transformation. (D) PCA plot. The 8 samples shown in the 2D plane spanned by the first three principal components. The results are presented as mean \pm SD. All experiments were repeated at least three times. 
identified 3 genes involved in steroidogenesis of granulosa cells that are downregulated including FSHR, CYP19A1 and $H S D 17 \beta$ (Supplementary Figure 3, Table 3 ).

\section{ZEA exposure affects porcine granulosa cell steroidogenesis}

We screened the frequent DEG encoded protein interactions of the PPI network using the STRING (http:// string-db.org/) analysis tool. In Supplementary Figure 4, several PPI nodes had higher degrees, as follows: TGF- $\beta$
$($ degree $=43), I G F-1($ degree $=26), E D N-1($ degree $=$ $24), I E R-3($ degree $=24)$. The results indicated that these proteins directly or indirectly interacted with other DEGs and regulated the DEGs functions. The most frequent DEG encoded protein interactions shared by the networks are shown in Supplementary Figure 5. There were 3 hub genes with higher degrees, including FSHR (degree = $31)$, CYP19A1 (degree $=27)$, and HSD17 $\beta$ (degree $=27)$. Notably, HSD17,$C Y P 19 A 1$ and FSHR were involved in direct or indirect interaction with steroidogenesis (Supplementary Figure 5). These enzymes or enzyme-
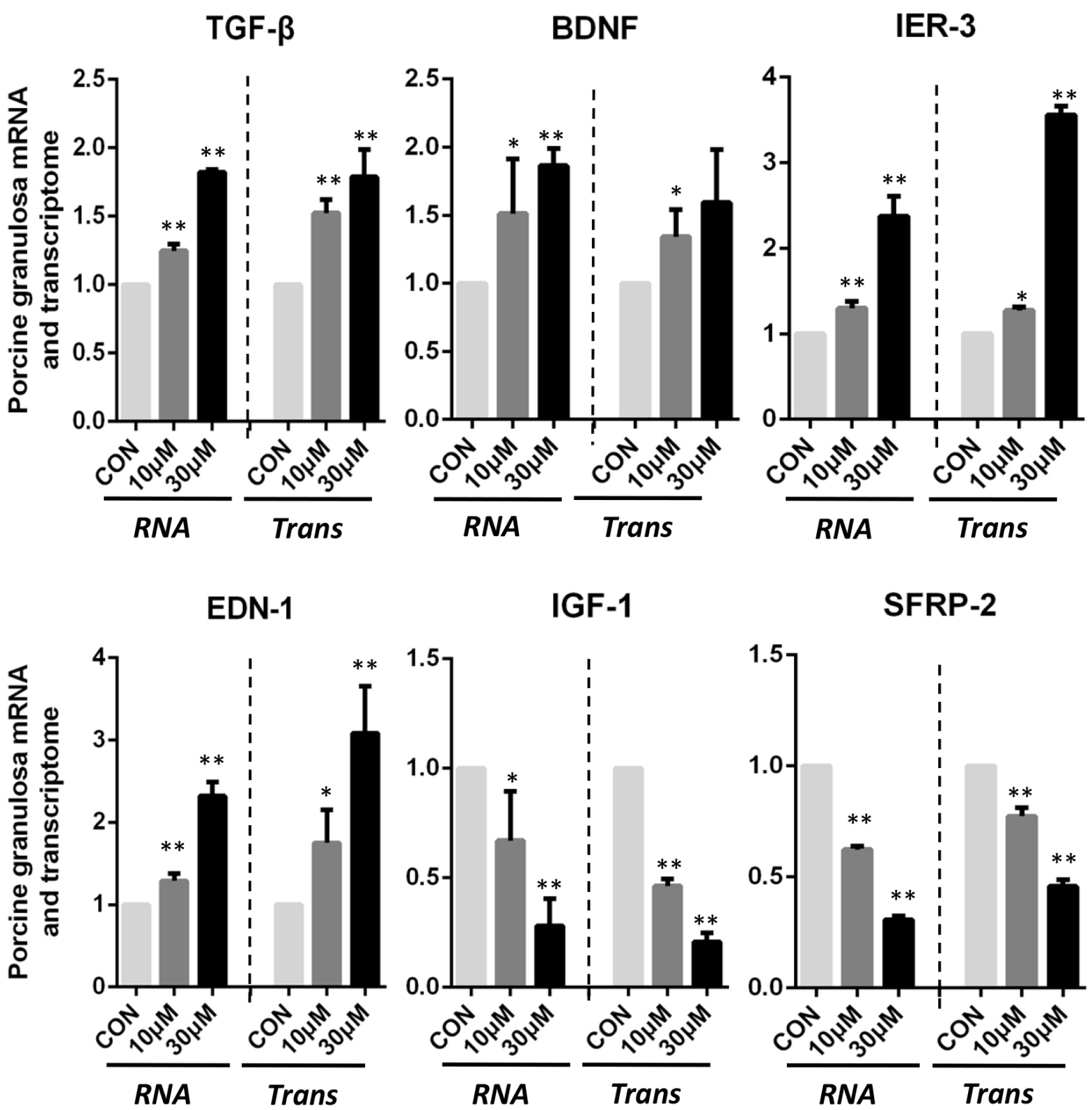

Figure 3: ZEA exposure affected the mRNA abundance of genes in the cultured granulosa cells. Granulosa cells incubated with ZEA for $72 \mathrm{~h}$. Quantitative RT-PCR for $T G F-\beta, B D N F$, IER-3, EDN-1, IGF-1 and SFRP-2 transcription factors. The mRNA level of all genes was normalized to the porcine granulosa cells $G A P D H$ gene. The results are presented as mean \pm SD. All experiments were repeated at least three times. $* P<0.05 ; * * P<0.01$. 
related proteins on steroidogenesis were expressed in ovarian granulosa cells. The $\mathrm{E}_{2}$ would be inhibited with the reduction of these steroidogenic enzymes.

On the basis of the results reported above we predicted that ZEA exposure impacted the steroidogenesis of granulosa cells by causing downregulation of transcripts for critical enzymes involved in the estrogen pathway. To verify such a possibility, we compared the expression level of several transcript factors and enzymes involved in the pathway in the control and ZEA-treated granulosa cells both at the mRNA and protein level. Q-PCR analyses showed that ZEA exposure significantly down-regulated the mRNA abundance of FSHR, $C Y P 19 A 1$ and HSD $17 \beta$ genes $(P<0.05$ or $P<$ 0.01 ; Figure $5 \mathrm{~A})$. As shown in Figure 5B, ZEA-treated granulosa cells had lower protein levels of FSHR (10

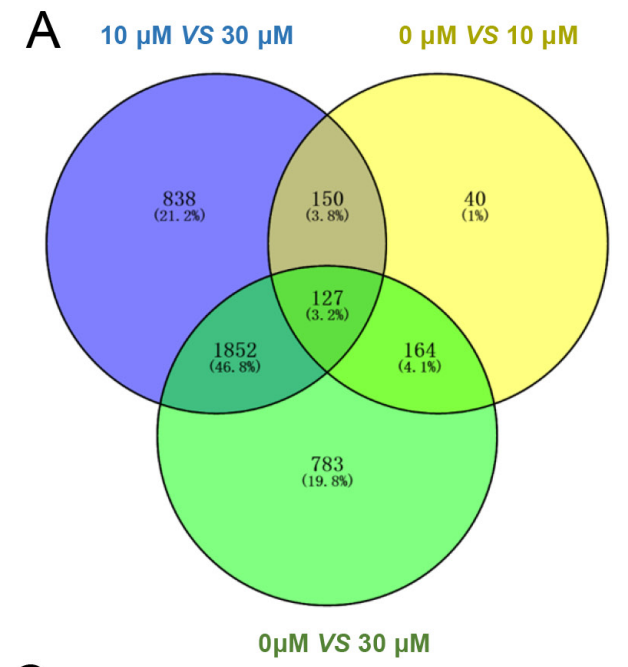

B

C
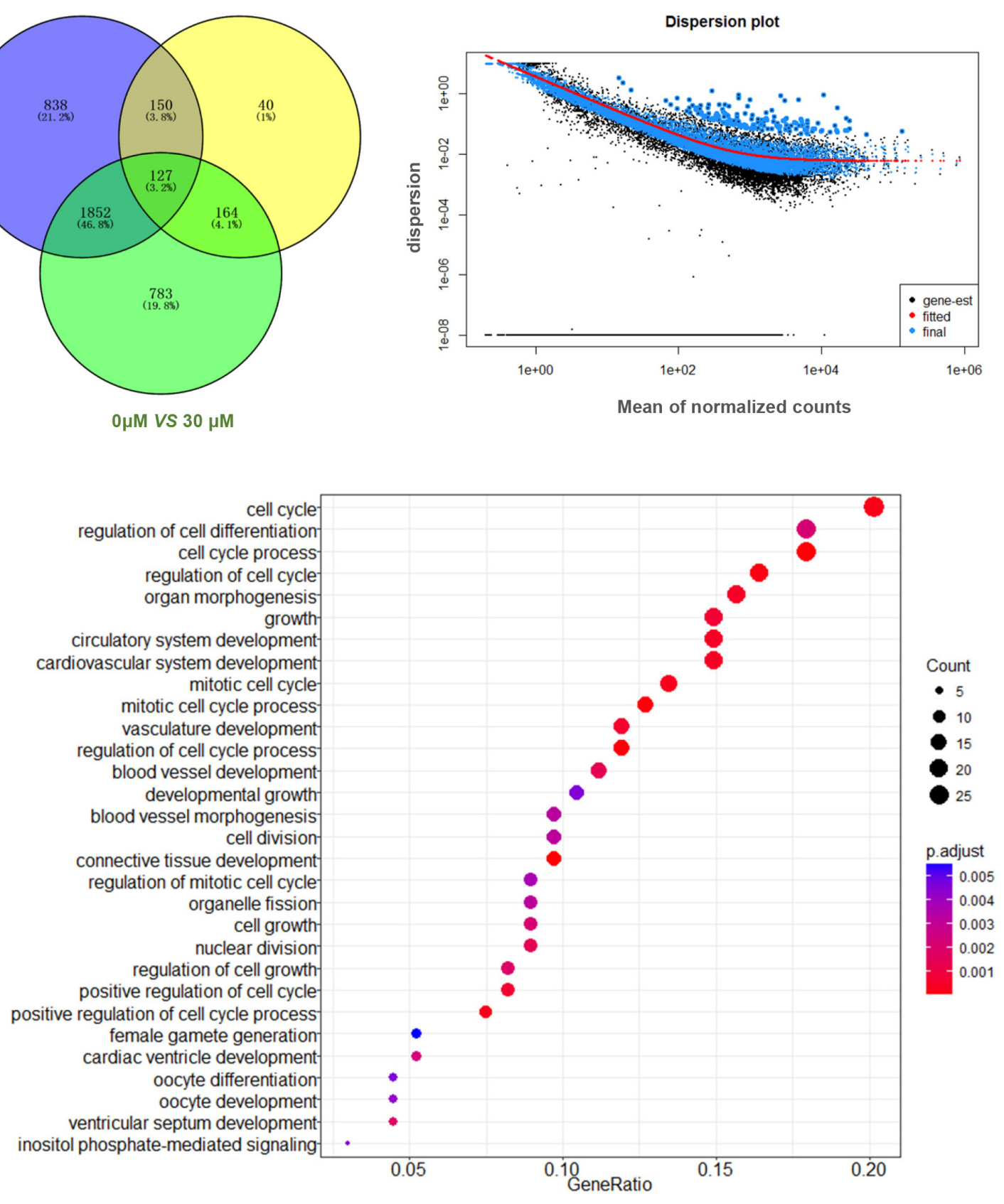

Figure 4: Gene expression of RNA-seq analysis in granulosa cells between control and ZEA-treated groups. (A) Venn diagram showed that the different expression of 3954 genes in control and ZEA-treated groups. (B) Dispersion plot. The dispersion estimate plot shows the gene-wise estimates (black), the fitted values (red), and the final maximum a posteriori estimates used in testing (blue). (C) Scattergram of overrepresented GO terms in biological process categories. 
Table 1: Analysis of gene ontology (GO) biological process of differentially expressed genes (DEGs)

\begin{tabular}{|c|c|c|c|c|c|}
\hline GO ID & Description & Term type & p_Value & q_Value & Count \\
\hline GO:0030282 & bone mineralization & biological_process & $9.02 \mathrm{E}-06$ & 0.007386 & 5 \\
\hline GO:0007049 & cell cycle & biological_process & $1.66 \mathrm{E}-05$ & 0.007386 & 7 \\
\hline GO:0031214 & $\begin{array}{c}\text { biomineral tissue } \\
\text { development }\end{array}$ & biological_process & $2.62 \mathrm{E}-05$ & 0.007751 & 5 \\
\hline GO:0007067 & Mitosis & biological_process & 7.97E-05 & 0.016073 & 5 \\
\hline GO:0009887 & organ morphogenesis & biological_process & $9.25 \mathrm{E}-05$ & 0.016073 & 10 \\
\hline GO:0000904 & $\begin{array}{l}\text { cell morphogenesis } \\
\text { involved in } \\
\text { differentiation }\end{array}$ & biological_process & 0.000109 & 0.016073 & 8 \\
\hline GO:0044236 & $\begin{array}{l}\text { multicellular organism } \\
\text { metabolic process }\end{array}$ & biological_process & 0.000182 & 0.023138 & 3 \\
\hline
\end{tabular}

Table 2: Analysis of Kyoto Encyclopedia of Genes and Genomes (KEGG) pathways of DEGs

\begin{tabular}{lccccc}
\hline KEGG ID & Description & GeneRatio & p_Value & q_Value & Count \\
\hline $\operatorname{ssc} 04970$ & $\begin{array}{c}\text { Salivary secretion } \\
\text { TGF- } \beta \text { signaling } \\
\text { pathway }\end{array}$ & $5 / 40$ & $4.62 \mathrm{E}-05$ & 0.004278 & 5 \\
$\operatorname{ssc04350}$ & $\begin{array}{c}\text { Gap junction } \\
\text { GnR signaling } \\
\operatorname{ssc} 04540\end{array}$ & $4 / 40$ & 0.000737 & 0.030238 & 4 \\
$\operatorname{ssc} 04912$ & $4 / 40$ & 0.001306 & 0.030238 & 4 \\
\hline
\end{tabular}

Table 3: Core genes expression of RNA-seq analysis in granulosa cells between control and $10 \mu \mathrm{M}$ ZEA-treated groups

\begin{tabular}{lccccc}
\hline Gene id & Sample $\mathbf{0} \boldsymbol{\mu M}$ & Sample 10 $\boldsymbol{\mu M}$ & Log $\mathbf{2}$ FoldChange & p_Value & q_Value \\
\hline$T G F-\beta$ & 32.7635 & 53.1452 & -0.69785 & $5.00 \mathrm{E}-05$ & 0.000932 \\
$B D N F$ & 27.2512 & 36.5626 & -0.42405 & 0.0019 & 0.021078 \\
$S F R P-2$ & 325.921 & 237.694 & 0.455414 & $5.00 \mathrm{E}-05$ & 0.000932 \\
$I G F-1$ & 30.507 & 13.9171 & 1.13228 & $5.00 \mathrm{E}-05$ & 0.000932 \\
$E D N-1$ & 15.2035 & 26.63 & -0.80865 & $5.00 \mathrm{E}-05$ & 0.000932 \\
$I E R-3$ & 13.9081 & 17.983 & -0.37071 & 0.00545 & 0.048266 \\
\hline
\end{tabular}

$\mu \mathrm{M}: 0.65 \pm 0.02 ; 30 \mu \mathrm{M}: 0.44 \pm 0.03), C Y P 19 A 1(10 \mu \mathrm{M}$ : $0.81 \pm 0.03 ; 30 \mu \mathrm{M}: 0.35 \pm 0.02)$ and $H S D 17 \beta(10 \mu \mathrm{M}$ : $0.71 \pm 0.04 ; 30 \mu \mathrm{M}: 0.43 \pm 0.04)$ than that of the control granulosa cells $(P<0.05$ or $P<0.01)$.

Interestingly, compared to the control groups, the co-treatment of $5 \mu \mathrm{g} / \mathrm{ml} \mathrm{FSH}$ and ZEA $(10 \mu \mathrm{M}$ or $30 \mu \mathrm{M})$ treatment groups showed no significantly decreased level of $\mathrm{E}_{2}$ in the granulosa cells, while the $10 \mu \mathrm{M}$ and $30 \mu \mathrm{M}$ ZEA treated groups showed significantly decreased level of $\mathrm{E}_{2}$. In addition, $5 \mu \mathrm{g} / \mathrm{ml} \mathrm{FSH}$ treatment significantly increased the level of $\mathrm{E}_{2}$ in the granulosa cells. These results indicated that $\mathrm{FSH}$ might rescue the decreased level of $\mathrm{E}_{2}$ observed in the ZEA treatment groups $(P<0.05$ or $P<0.01$; Figure 6).

In addition, we propose a possible mechanism of ZEA exposure disrupting the steroidogenesis by DEGs enriched in the pathway of ovarian steroidogenesis and the results of ZEA exposure on the granulosa cells (Figure 7).

\section{DISCUSSION}

Numerous studies have focused on the effects of endocrine disrupting chemicals (EDCs) on female reproduction. We previously found that ZEA led to 
apoptosis of ovarian germ cells, altered gene expression and impaired the formation of primordial follicle in the newborn mouse [17]. We suspected that ZEA altered the development and steroidogenesis of ovarian granulosa cells, which in turn caused indirect effects on mammalian fertility. To our knowledge, there is little information about the comprehensive molecular mechanisms of porcine granulosa cells development and steroidogenesis influenced by ZEA.

Using RNA-seq analysis, we found that ZEA exposure significantly altered the mRNA expression of hundreds of genes in the granulosa cells. In particular,
$T G F-\beta$ and SMAD-7 genes were found to be upregulated and downregulated, respectively, suggesting ZEA exposure is involved in the antiproliferative response to $T G F-\beta$ [18]. For example, $T G F-\beta$ induces the dephosphorylation of p70S6K by PP2A, which leads to cell cycle arrest [19]. With the regulation of the cell cycle or cell differentiation, $T G F-\beta$ and SMAD-7 can trigger apoptosis. Mechanisms of $T G F-\beta$ induced apoptosis include an increase in the expression of death associated protein kinase $D A P K$ [20] and the binding of the proapoptotic effector to $\mathrm{Bcl}-2$ in gastric carcinoma cell lines [21]. In addition, Zhu et al. have demonstrated that high concentrations of ZEA $(>$

A

CYP19A1

FSHR

HSD17 $\beta$

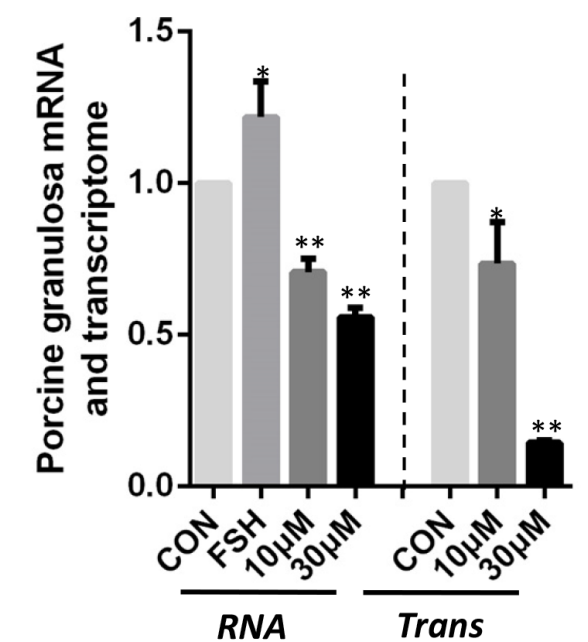

B

ZEA
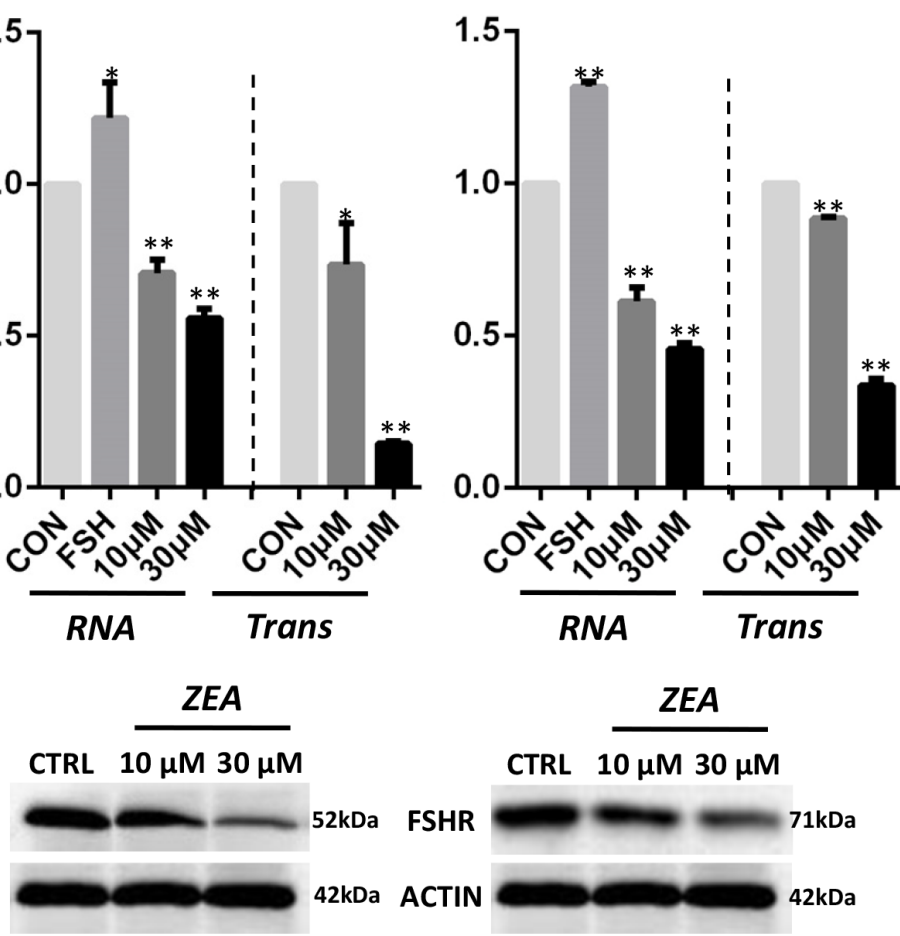

CYP19A1
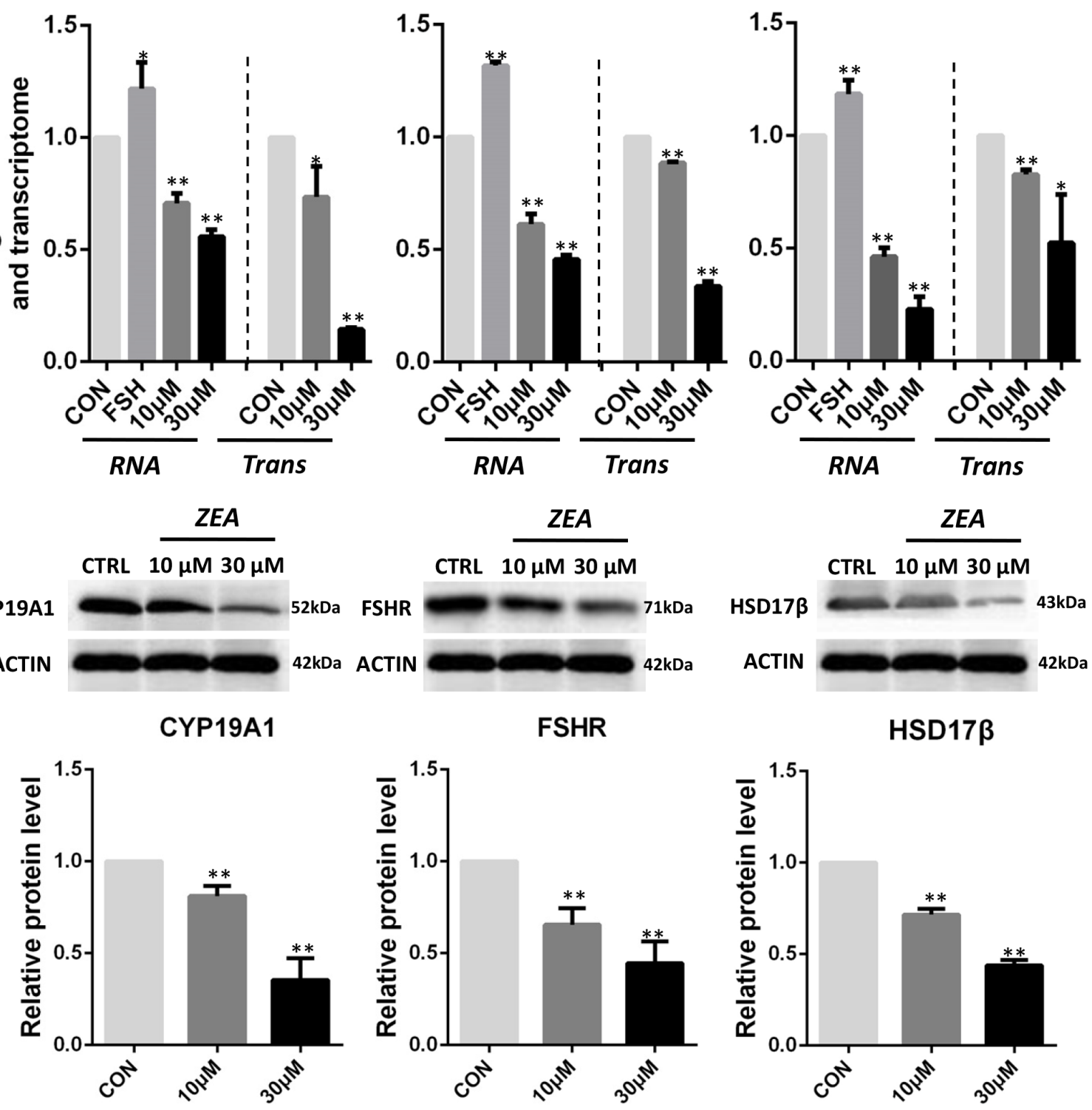

Figure 5: ZEA exposure affected the mRNA and protein abundance of steroidogenesis-related genes in cultured granulosa cells. (A) Quantitative RT-PCR for CYP19A1, FSHR, and $H S D 17 \beta$ transcription factors. The mRNA levels of all genes was normalized to the porcine granulosa cells GAPDH gene. (B) Protein levels of CYP19A1/ACTIN, FSHR/ACTIN, and HSDI7 $/ A C T I N$ by western blotting. The protein levels was normalized to $A C T I N$. The results are presented as mean $\pm \mathrm{SD}$. All experiments were repeated at least three times. $* P<0.05 ; * * P<0.01$. 


\section{$17 \beta$-estradiol}

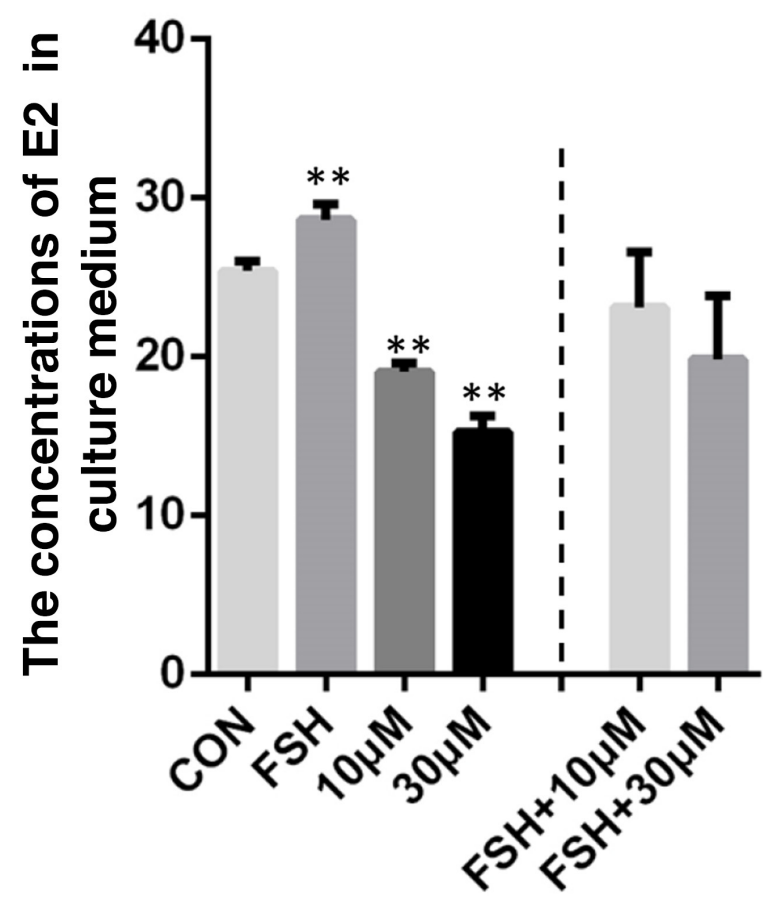

Figure 6: 17ß-estradiol $\left(\mathbf{E}_{2}\right)$ level in granulosa cells-culture medium. ZEA exposure resulted in a significant reduction in the concentrations of $\mathrm{E}_{2}$ in granulosa cells-culture medium and could be rescued by FSH. The results are presented as mean $\pm \mathrm{SD}$. All experiments were repeated at least three times. $* P<0.05 ; * * P<0.01$.

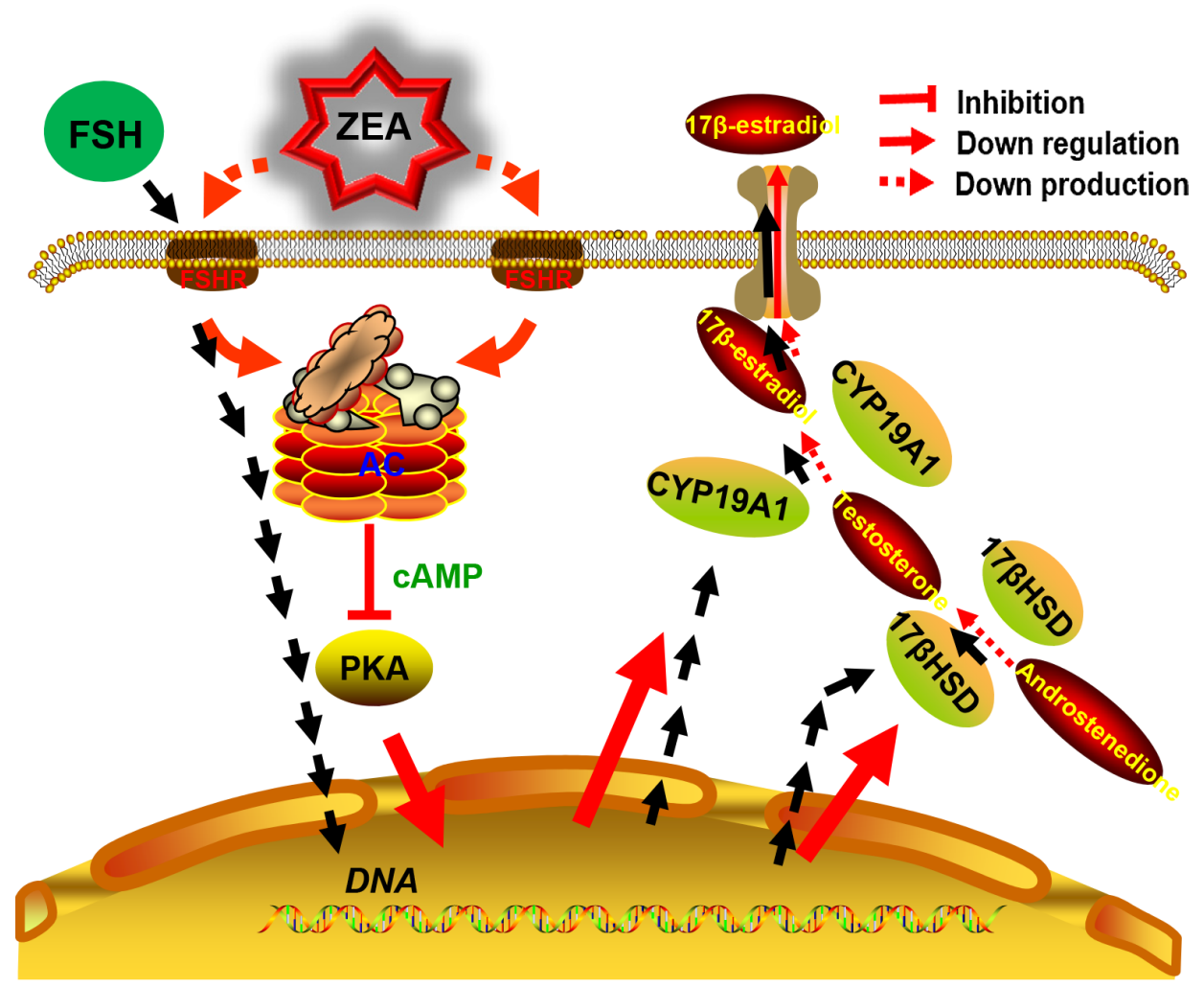

Figure 7: The diagram showed steroidogenesis pathways affected by FSH and the likely mechanisms for decreasing steroidogenesis induced by ZEA-exposure in granulosa cells. 
$60 \mu \mathrm{M}$ ) increases reactive oxygen species (ROS) levels, decreases the proliferation of porcine granulosa cells and causes an obvious apoptosis and necrosis in porcine granulosa cells [16]. Our results indicated that low concentrations $(10 \mu \mathrm{M})$ of ZEA exposure may increase ROS production via the $T G F-\beta$ pathway by repressing the expression of antioxidant genes or by activating the expression of NADPH oxidase (Nox) [22, 23]. TGF- $\beta$ induced ROS production can promote granulosa cell apoptosis through a mitochondrial-dependent pathway, or at least partially through the modulation of the $\mathrm{Bcl}$ 2 family [24]. These results, together with our previous studies, suggest that ZEA may induce the apoptosis of granulosa cells via disrupting the $T G F-\beta$ pathway $[17,19$, 23].

Bioinformatics analyses confirmed that $I G F-I$ and steroidogenesis related genes were particularly affected in the ZEA exposed granulosa cells. A previous study showed that FSHR and $I G F-I$ gene are expressed in the granulosa cells of healthy growing follicles in the ovary [25]. The reduction in FSHR mRNA and aromatase expression was detected in the follicles of $I G F-I$ knockout mice. Moreover, the reduced level of granulosa cell FSHR expression in $I G F-I$ knockout ovaries led to the infertility in the female [26]. Interestingly, we found ZEA exposure down regulated the expression of $I G F-I$ and FSHR genes which was the regulator of enzymes involved in steroidogenesis. However, local IGF-I expression is not essential for induction of granulosa cell FSHR gene expression de novo, since FSHR mRNA is still present, albeit at low levels, in the $I G F-I$ knockout ovary [26]. $I G F-I$ was related to the production of certain proteins that stabilize the FSHR mRNA in granulosa cells [27]. It is possible that ZEA has a primary effect on granulosa cell FSHR expression, and that $I G F-I$ secondarily reduces FSHR expression to decrease the response to FSH.

On the other hand, most of the effects of endocrine disrupters on female reproduction have been attributed to their capability to deregulate steroid signaling at various levels [1, 28, 29]. The production of ovarian steroids relies on a series of receptors and steroidogenic enzymes expressed in theca or granulosa cells [30]. In the present study we found that ZEA exposure caused decreased mRNA levels of genes encoding crucial players involved in steroidogenic pathways mainly in granulosa cells such as the receptor of FSH and the enzymes CYP19A1 and $H S D 17 \beta$. Western-blot results confirmed decreased expression of CYP19A1 and $H S D 17 \beta$ proteins in the ZEA exposed granulosa cells. In addition, in line with previous in vivo and in vitro studies, we found that ZEA decreased the level of ovarian PROG, $E_{2}$ and ASD. A direct inhibition of the transcription of aromatase genes and/or the enzyme activity via $F S H$ plus $I G F-I$ induced CYP19A1 and CYP11A1 mRNA abundance by ZEA may be the mechanism of these effects [31]. The alterations of granulosa cell mitochondria observed by us also supports the impact of ZEA on steroidogenesis [24]. Though ZEA did not appear to affect follicle dynamics, it might be the cause of the reduction of the systemic level of $E_{2}$ observed in the exposed animals. Interestingly, ZEA exposure resulted in a significant reduction in the concentrations of $E_{2}$ in granulosa cell-culture medium. In mammals the steroid hormones produced by growing follicles serve as feedback signals to the hypothalamus and pituitary gland in order to establish a hormonal regulatory axis [32].

As reported above, results of the present study indicated that ZEA had direct dose-dependent effects on granulosa cell steroidogenesis. It is probable that porcine granulosa cells are the main targets of the ZEA as reported in the present study. What's more, we have developed an innovative, integrated method to hunt novel hubs associated with ZEA exposure on granulosa cells at a low cost. Up-regulated hub genes $E D N-1, I E R-3, T G F-\beta$ and $B D N F$, down-regulated hub genes $I G F-1, S F R P$ 2 , and estrogen synthesis related genes such as FSHR, $C Y P 19 A 1$ and HSD17 $\beta$ might play important roles in the toxic effects of ZEA. These interactions and direct ovarian effects could be an important mechanism of the pollutant ZEA in feedstuffs impacting reproductive performance in swine.

\section{MATERIALS AND METHODS}

\section{Reagents}

ZEA (Z2125-10 MG) was purchased from Sigma (St. Louis, MO). Dimethyl sulfoxide (DMSO), M-199 medium, penicillin, streptomycin and fetal bovine serum (FBS) were obtained from Gibco (Carlsbad, CA). Stock solutions of ZEA were prepared by dissolving ZEA in DMSO.

\section{Animals}

The ovaries of mature sows were collected from Qingdao Fu Wan Pig Production Cooperation (Qingdao, China). Porcine ovaries were obtained from a local slaughterhouse and maintained at $30-37^{\circ} \mathrm{C}$ for isolation of granulosa cells. The procedures of animal handling were reviewed and approved by the Ethical Committee of Qingdao Agricultural University (agreement No. 201518).

\section{Isolation and culture of porcine granulosa cells}

Granulosa cells were aspirated aseptically from antral follicles (about $4 \mathrm{~mm}$ diameter) using a $20 \mathrm{ml}$ syringe (18-gauge needles) [16]. After standing for $15 \mathrm{~min}$, the granulosa cells were centrifuged at $300 \mathrm{~g}$ for $5 \mathrm{~min}$ according to the methods previously described [23]. The blood cells in the supernatant were aspirated after rinsing with phosphate-buffered saline (PBS). Then the granulosa 
cells were cultured in M-199 medium supplemented with $10 \%$ FBS and $1 \%$ penicillin-streptomycin in a humidified incubator with $5 \% \mathrm{CO}_{2}$ at $37^{\circ} \mathrm{C}$ [33].

\section{Drug treatments}

Granulosa cells were seeded into $6 \mathrm{~cm}$ culture dishes; at a density of $1 \times 10^{6}$ cells per dish. To study the generation of mRNA and protein expression in the ZEAtreated granulosa cells, ZEA was added to the medium at final concentrations of $10 \mu \mathrm{M}$ and $30 \mu \mathrm{M}$ and the cells were incubated for $72 \mathrm{~h}$. To investigate the protective mechanism of FSH against ZEA-induced intracellular damage, cells were treated with or without $5 \mu \mathrm{g} / \mathrm{ml} \mathrm{FSH}$ for $72 \mathrm{~h}$ co-treated with ZEA. Control groups set up with DMSO at the same concentrations treated with ZEA is to guarantee the accuracy of experimental design.

\section{TUNEL staining}

TUNEL BrightRed Apoptosis Detection Kit (Vazyme, A11302, Nanjing, China) was used to evaluate the granulosa cell apoptosis following the manufacturer's instructions. Briefly, after $72 \mathrm{~h}$ ZEA treatment, the granulosa cells were collected by digestion with collagenase $(0.2 \%$ in PBS) for 6 min and fixed in $4 \%$ paraformaldehyde for 2 h. After dripped onto the slides, the cells were heated at 42 ${ }^{\circ} \mathrm{C}$ for $1 \mathrm{~h}$. Then the slides of granulosa cells were washed twice with PBS. After incubation with $60 \mu \mathrm{T}$ TUNEL reaction mixture (Label Solution and Enzyme Solution; 5:1) following the manufacturer's recommendations, for $60 \mathrm{~min}$ at $37^{\circ} \mathrm{C}$ without light, the granulosa cells were stained with DAPI and photographed with a fluorescence microscope. Five different areas were randomly selected from each section to calculate TUNEL positive cells under microscope. The calculations were conducted at least three independent experiments.

\section{RNA extraction, reverse transcription, and RNA-Seq}

Porcine granulosa cells were harvested and extracted for total RNA using an RNAprep pure MicroKit (Aidlab, RN07, Beijing, China) according to the manufacturer's protocols. And the cDNAs were synthesized using a TURE script first strand cDNA Synthesis Kit (Aidlab, PC1802, Beijing, China) as described [34]. The reaction program was: $40 \mathrm{~min}$ at $42{ }^{\circ} \mathrm{C}, 65^{\circ} \mathrm{C}$ for $15 \mathrm{~min}$, and finally a cooling step at $4{ }^{\circ} \mathrm{C}$. For RNA-Seq, control and treatment granulosa cells were collected after in vitro ZEA exposure for $72 \mathrm{~h}$. In each group, we applied 3 independent samples to extract total RNA using TRIZOL and sequenced at Novogene (Beijing, China).

\section{Data preprocessing and identification of DEGs}

The sequencing data is subjected to quality control to obtain clean data. The clean reads were compared to the
Sus_scrofa10.2 reference genome using HISAT2 software. Using featureCounts software to obtain gene expression levels. The CONTROL-3 sample correlation of RNA-seq was found to be different to other CONTROL sample group. Remove this samples in order not to affect subsequent analysis. Use R package DESeq2 for differential expression analysis. The classical Hypergeometric distribution test was applied in our analysis to check the GO enrichment analysis and KEGG analysis in 3 groups. The Benjamini \& Hochberg method [35] was used to adjust the raw $\mathrm{p}$ value into the false discovery rate (FDR). Adjusted $q$-value $<0.1$ were regarded as the cutoff criterion for DEGs.

\section{GO enrichment analysis}

Based on Gene Ontology Database (http://www. geneontology.org/), the functions of DEGs between control and ZEA-treated samples were analyzed via $\mathrm{GO}$, which is a commonly used approach for functional enrichment studies of large-scale genes [36]. Use the $\mathrm{R}$ package clusterProfiler for GO enrichment analysis $p$-value $<0.01$ and adjusted $p$-value $<0.1$ were regarded as the cutoff criterion for $\mathrm{GO}$ enrichment analysis.

\section{Pathway enrichment analysis}

KEGG is a bioinformatics database including biochemistry pathways [37]. R package clusterProfiler provides analytic ways for extracting biological meaning from a large list of genes [38]. The R package clusterProfiler was used for KEGG pathway enrichment analysis DEGs. Screaming some pathways were analyzed for significant differences. $p$-value $<0.01$ and adjusted $p$-value $<0.1$ were regarded as the cutoff criterion for KEGG enrichment analysis.

\section{PPI network construction and modules mining}

As proteins seldom perform their functions alone, it is important to comprehend the interaction of these proteins by studying larger functional groups of proteins [39]. The STRING database [40] provides both experimental and predicted interaction information. We used the STRING database to annotate functional interactions between DEGs. The edges and nodes of the PPI network were so complicated [38] that further analysis was needed to expose the enriched functional modules of the PPI network using STRING (http://string-db.org/) process [41]. Based on this information, a PPI network was visualized by Cytoscape [42].

\section{Quantitative real-time PCR}

Supplementary Table 1 listed the primers used in this study. A LightCycler 480 real-time PCR instrument (Roche LC480) was used to carry out amplification using a Light CyclerVR SYBR Green I Master (Roche, 04887352001, Germany). Amplification was performed 
in a $20 \mu \mathrm{l}$ reaction solution following the manufacturer's recommendations, containing $2 \mu \mathrm{l}$ cDNA, $10 \mu \mathrm{l}$ of SYBR green master mix, $0.8 \mu \mathrm{l}$ of primers $(20 \mu \mathrm{M})$, and $7.2 \mu \mathrm{l}$ of nuclease-free water. The PCR reaction conditions: $10 \mathrm{~min}$ at $95^{\circ} \mathrm{C}$, followed by 45 cycles of $95^{\circ} \mathrm{C}$ for 10 $\mathrm{s}, 60{ }^{\circ} \mathrm{C}$ for $30 \mathrm{~s}$ and finally a cooling step at $4{ }^{\circ} \mathrm{C}$. The mRNA abundance of reference gene was normalized

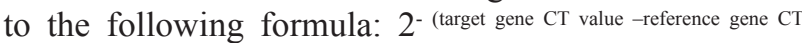
value). Each amplification was done in triplicate and the gene expression was normalized using the standard curve generated with $G A P D H$ as the reference gene. We provided the standard curve and primer efficiency of all the primers in the Supplementary Figure 1.

\section{Western blotting}

Protein lysates isolated from control and ZEA exposed granulosa cells were used for western blotting analysis according to standard methods [43, 44]. The proteins from each group were separated by SDS-PAGE and were transferred onto PVDF membranes. Following blocking with $5 \%$ BSA in Tris-buffered saline, $\mathrm{pH} 7.4$, containing $0.05 \%$ Tween-20 (TBST), the membranes were incubated with anti-ACTIN antibody (Abcam, ab8226), rabbit anti-FSHR antibody (Sangon, D120641), rabbit anti-HSD17 $\beta$ antibody (Sangon, D261765), rabbit anti-CYP19A1 antibody (Sangon, D260102), at the concentration of $1.0 \mu \mathrm{g} / \mathrm{ml}$, overnight at $4{ }^{\circ} \mathrm{C}$. Then the membranes were incubated at $37{ }^{\circ} \mathrm{C}$ for $2 \mathrm{~h}$ with secondary antibodies (Beyotime, A0208) at a dilution of 1:1500 in TBST after washing three times in TBST. The band intensity was quantified using Actin as internal control and measured with IPWIN software.

\section{Dosage of sex steroid hormones}

The levels of $\mathrm{E}_{2}$ was assessed in granulosa cell culture medium using ELISA kits (LanpaiBIO, China) following the manufactures' protocol. All samples were run in triplicates, and all coefficient of linear regression meet a criterion $(\mathrm{R} 2>0.92)$.

\section{Statistical methods}

Data are represented as mean \pm SD. Differences between the control and treatment groups were statistically determined by one-way analysis of variance (ANOVA) followed by Tukey test for multiple comparisons using Graph-Pad Prism analysis software (Graph-Pad Software, San Diego, CA). Results were considered statistically significant at $P<0.05$.

\section{ACKNOWLEDGMENTS}

The authors are grateful to Dr. Paul W. Dyce for his suggestions on the manuscript.

\section{CONFLICTS OF INTEREST}

The authors fully declare any financial or other potential conflicts of interest.

\section{FUNDING}

This work was supported by National Natural Science Foundation of China (31572225), National Key Research and Development Program of China (2016YFD0501207), Construction of E-Jiao Standardization (ZYBZH-Y-SD-31), and Natural Science Foundation of Heilongjiang Province of China (ZD201304).

\section{REFERENCES}

1. Kuiper-Goodman T, Scott PM, Watanabe H. Risk assessment of the mycotoxin zearalenone. Regul Toxicol Pharmacol. 1987; 7: 253-306.

2. Poor M, Kunsagi-Mate S, Sali N, Koszegi T, Szente L, Peles-Lemli B. Interactions of zearalenone with native and chemically modified cyclodextrins and their potential utilization. J Photochem Photobiol B. 2015; 151: 63-68.

3. Biehl ML, Prelusky DB, Koritz GD, Hartin KE, Buck WB, Trenholm HL. Biliary excretion and enterohepatic cycling of zearalenone in immature pigs. Toxicol Appl Pharmacol. 1993; 121: 152-159.

4. Sambuu R, Takagi M, Shiga S, Uno S, Kokushi E, Namula Z, Otoi T, Miyamoto A, Deguchi E, Fink-Gremmels J. Detection of zearalenone and its metabolites in naturally contaminated porcine follicular fluid by using liquid chromatography-tandem mass spectrometry. J Reprod Dev. 2011; 57: 303-306.

5. Vanyi A, Bata A, Glavits R, Kovacs F. Perinatal oestrogen syndrome in swine. Acta Vet Hung. 1994; 42: 433-446.

6. Obremski K, Gajecki M, Zwierzchowski W, Zielonka L, Otrocka-Domagala I, Rotkiewicz T, Mikolajczyk A, Gajecka M, Polak M. Influence of zearalenone on reproductive system cell proliferation in gilts. Pol J Vet Sci. 2003; 6: 239-245.

7. Zwierzchowski W, Przybylowicz M, Obremski K, Zielonka L, Skorska-Wyszynska E, Gajecka M, Polak M, Jakimiuk E, Jana B, Rybarczyk L, Gajecki M. Level of zearalenone in blood serum and lesions in ovarian follicles of sexually immature gilts in the course of zearalenone micotoxicosis. Pol J Vet Sci. 2005; 8: 209-218.

8. Katzenellenbogen BS, Korach KS. A new actor in the estrogen receptor drama--enter ER-beta. Endocrinology. 1997; 138: 861-862.

9. Eppig JJ, Wigglesworth K, Pendola FL. The mammalian oocyte orchestrates the rate of ovarian follicular development. Proc Natl Acad Sci U S A. 2002; 99: 2890-2894. 
10. Payne AH, Hales DB. Overview of steroidogenic enzymes in the pathway from cholesterol to active steroid hormones. Endocr Rev. 2004; 25: 947-970.

11. Kotsuji F, Tominaga $\mathrm{T}$. The role of granulosa and theca cell interactions in ovarian structure and function. Microsc Res Tech. 1994; 27: 97-107.

12. Edson MA, Nagaraja AK, Matzuk MM. The mammalian ovary from genesis to revelation. Endocr Rev. 2009; 30: 624-712.

13. Peluso C, Fonseca FL, Rodart IF, Cavalcanti V, Gastaldo G, Christofolini DM, Barbosa CP, Bianco B. AMH: an ovarian reserve biomarker in assisted reproduction. Clin Chim Acta. 2014; 437: 175-182.

14. Tao YX, Segaloff DL. Follicle stimulating hormone receptor mutations and reproductive disorders. Prog Mol Biol Transl Sci. 2009; 89: 115-131.

15. Hannon PR, Flaws JA. The effects of phthalates on the ovary. Front Endocrinol (Lausanne). 2015; 6: 8.

16. Zhu L, Yuan H, Guo C, Lu Y, Deng S, Yang Y, Wei Q, Wen L, He Z. Zearalenone induces apoptosis and necrosis in porcine granulosa cells via a caspase-3- and caspase-9dependent mitochondrial signaling pathway. J Cell Physiol. 2012; 227: 1814-1820.

17. Zhang GL, Sun XF, Feng YZ, Li B, Li YP, Yang F, Nyachoti CM, Shen W, Sun SD, Li L. Zearalenone exposure impairs ovarian primordial follicle formation via down-regulation of Lhx8 expression in vitro. Toxicol Appl Pharmacol. 2017; 317: 33-40.

18. Derynck R, Zhang YE. Smad-dependent and Smadindependent pathways in TGF-beta family signalling. Nature. 2003; 425: 577-584.

19. Petritsch C, Beug H, Balmain A, Oft M. TGF-beta inhibits p70 S6 kinase via protein phosphatase 2A to induce $\mathrm{G}(1)$ arrest. Genes Dev. 2000; 14: 3093-3101.

20. Jang CW, Chen $\mathrm{CH}$, Chen CC, Chen JY, Su YH, Chen RH. TGF-beta induces apoptosis through Smad-mediated expression of DAP-kinase. Nat Cell Biol. 2002; 4: 51-58.

21. Ohgushi M, Kuroki S, Fukamachi H, O'Reilly LA, Kuida K, Strasser A, Yonehara S. Transforming growth factor beta-dependent sequential activation of Smad, Bim, and caspase-9 mediates physiological apoptosis in gastric epithelial cells. Mol Cell Biol. 2005; 25: 10017-10028.

22. Herrera B, Alvarez AM, Beltran J, Valdes F, Fabregat I, Fernandez M. Resistance to TGF-beta-induced apoptosis in regenerating hepatocytes. J Cell Physiol. 2004; 201: 385-392.

23. Qin X, Cao M, Lai F, Yang F, Ge W, Zhang X, Cheng S, Sun X, Qin G, Shen W, Li L. Oxidative stress induced by zearalenone in porcine granulosa cells and its rescue by curcumin in vitro. PLoS One. 2015; 10: e0127551.

24. Ramjaun AR, Tomlinson S, Eddaoudi A, Downward J. Upregulation of two BH3-only proteins, Bmf and Bim, during TGF beta-induced apoptosis. Oncogene. 2007; 26: 970-981.
25. Zhou J, Kumar TR, Matzuk MM, Bondy C. Insulin-like growth factor I regulates gonadotropin responsiveness in the murine ovary. Mol Endocrinol. 1997; 11: 1924-1933.

26. Baker J, Hardy MP, Zhou J, Bondy C, Lupu F, Bellve AR, Efstratiadis A. Effects of an Igf1 gene null mutation on mouse reproduction. Mol Endocrinol. 1996; 10: 903-918.

27. Minegishi T, Hirakawa T, Kishi H, Abe K, Abe Y, Mizutani T, Miyamoto K. A role of insulin-like growth factor I for follicle-stimulating hormone receptor expression in rat granulosa cells. Biol Reprod. 2000; 62: 325-333.

28. Li L, Liu JC, Zhao Y, Lai FN, Yang F, Ge W, Dou CL, Shen W, Zhang XF, Chen H. Impact of diethylhexyl phthalate on gene expression and development of mammary glands of pregnant mouse. Histochem Cell Biol. 2015; 144: 389-402.

29. Lenie S, Smitz J. Steroidogenesis-disrupting compounds can be effectively studied for major fertility-related endpoints using in vitro cultured mouse follicles. Toxicol Lett. 2009; 185: 143-152.

30. Stocco DM. StAR protein and the regulation of steroid hormone biosynthesis. Annu Rev Physiol. 2001; 63: 193-213.

31. Ranzenigo G, Caloni F, Cremonesi F, Aad PY, Spicer LJ. Effects of Fusarium mycotoxins on steroid production by porcine granulosa cells. Anim Reprod Sci. 2008; 107: 115-130.

32. Ojeda SR, Urbanski HF, Ahmed CE. The onset of female puberty: studies in the rat. Recent Prog Horm Res. 1986; 42: 385-442.

33. Duda M, Knet M, Tabarowski Z, Slomczynska M. Luteal macrophage conditioned medium affects steroidogenesis in porcine granulosa cells. Reprod Biol. 2011; 11: 117-134.

34. Pan B, Chao H, Chen B, Zhang L, Li L, Sun X, Shen W. DNA methylation of germ-cell-specific basic helix-loophelix (HLH) transcription factors, Sohlh2 and Figlalpha during gametogenesis. Mol Hum Reprod. 2011; 17: 550-561.

35. Benjamini Y, Drai D, Elmer G, Kafkafi N, Golani I. Controlling the false discovery rate in behavior genetics research. Behav Brain Res. 2001; 125: 279-284.

36. Ashburner M, Ball CA, Blake JA, Botstein D, Butler H, Cherry JM, Davis AP, Dolinski K, Dwight SS, Eppig JT, Harris MA, Hill DP, Issel-Tarver L, et al. Gene ontology: tool for the unification of biology. The Gene Ontology Consortium. Nat Genet. 2000; 25: 25-29.

37. Kanehisa M, Goto S. KEGG: Kyoto encyclopedia of genes and genomes. Nucleic Acids Res. 2000; 28: 27-30.

38. Huang W, Kutner N, Bliwise DL. A systematic review of the effects of acupuncture in treating insomnia. Sleep Med Rev. 2009; 13: 73-104.

39. Srihari S, Leong HW. Temporal dynamics of protein complexes in PPI networks: a case study using yeast cell cycle dynamics. BMC Bioinformatics. 2012; 13 Suppl 17: S16. 
40. Franceschini A, Szklarczyk D, Frankild S, Kuhn M, Simonovic M, Roth A, Lin J, Minguez P, Bork P, von Mering C, Jensen LJ. STRING v9.1: protein-protein interaction networks, with increased coverage and integration. Nucleic Acids Res. 2013; 41: D808-15.

41. Beisser D, Klau GW, Dandekar T, Muller T, Dittrich MT. BioNet: an R-Package for the functional analysis of biological networks. Bioinformatics. 2010; 26: 1129-1130.

42. Smoot ME, Ono K, Ruscheinski J, Wang PL, Ideker T. Cytoscape 2.8: new features for data integration and network visualization. Bioinformatics. 2011; 27: 431-432.
43. Zhang P, Chao H, Sun X, Li L, Shi Q, Shen W. Murine folliculogenesis in vitro is stage-specifically regulated by insulin via the Akt signaling pathway. Histochem Cell Biol. 2010; 134: 75-82.

44. Chao HH, Zhang XF, Chen B, Pan B, Zhang LJ, Li L, Sun XF, Shi QH, Shen W. Bisphenol A exposure modifies methylation of imprinted genes in mouse oocytes via the estrogen receptor signaling pathway. Histochem Cell Biol. 2012; 137: 249-259. 